\title{
家畜に括ける Kanamycinの応用試験
}

\author{
有沢道弥* 高橋 健* 内野富弥* 渡辺 仙* 中井隆夫* 野田宗兵* 中村良一*
}

(昭和 40 年 7 月 20 日受付)

Kanamycin(以下 KM と略称) は梅沢ら12,13)によっ て発見され，その後基礎および臨床の両面から検討され た結果, この抗生物質はグラム陽性および陰性菌に作用 し，抗菌スペクトラムのきわめて広大なことがわかっ た. そして他種抗生物質に耐性を獲得したブドウ球菌, 大腸菌およびそのほかの多くの病原菌，とくに結核菌に 対しても有効なことが証明された.

KMの毒性については，梅沢ら12,13) は犬に 150〜300 $\mathrm{mg} / \mathrm{kg}$ 宛 2 月, また猫に $300 \mathrm{mg} / \mathrm{kg}$ 宛 1 月, それぞれ筋 注したところ，とくに障害はないとのべた。 TisCH らは 犬に 1 日 $100 \mathrm{mg} / \mathrm{kg}$ 宛 9 月筋肉内に, $1,000 \mathrm{mg} / \mathrm{kg}$ 宛 1 月経口的に, さらに猫に $100 \mathrm{mg} / \mathrm{kg}$ 宛 8 月皮下に, そ れぞれ注射または投与したところ，やはりなんら障害は 認めていない。 また TAKEUCHI ら抢よび MAEDA らの, 実験動物に対する毒性試験結果でも障害は発生しない. ただ堂野前によると，人に 1 日 $1 \sim 1.5 \mathrm{~g}$ 宛 1 週 $6 \mathrm{~g}$ 以 上与えると, 第 8 脳神経障害を発現するということであ る.

KMを筋注すると, 高い血中濃度を示して諸蔵器に分 布し，尿中に排泄されるほか1,3,9 13)髄液中11)では適切 な濃度を保ち，かつ胆汁の中にも移行する．長岐らは人 で, $2 \mathrm{~g}$ 投与群では 1 時間で 84〜100 r, また $1 \mathrm{~g}$ 群で は同じく 1 時間で $50 \sim 75 \gamma$ で，ともに最高濃度を示す が，以後は漸減して 4 時間で $1 / 2 \sim 1 / 3$ 以下となり， 24 時間ではほとんど消失したという.

著者らが馬について行なった実験では， $7.5 \mathrm{mg} / \mathrm{kg}$ を 筋注した場合， 2 時間では $14.1 \mu \mathrm{g} / \mathrm{ml}$ および 12 時間で は $0.8 \mu \mathrm{g} / \mathrm{ml}$ で，潮次血中濃度は低下した。 また $15 \mathrm{mg}$ $/ \mathrm{kg}$ を筋注した例では，2 時間では $55.0 \mu \mathrm{g} / \mathrm{ml}$ で最高 血中濃度を示し，ついで低下して 12 時間では $1.8 \mathrm{mcg}$ $/ \mathrm{ml}$ である. 牛では, $5 \mathrm{mg} / \mathrm{kg}$ を筋注した場合は30分で $12.7 \mu \mathrm{g} / \mathrm{ml}$ ，また $10 \mathrm{mg} / \mathrm{kg}$ を注射した場合は 3 時間で $19.7 \mu \mathrm{g} / \mathrm{ml}$ で，それぞれ最高濃度を示した。

また Tisch らの犬についての実験では, $50 \mathrm{mg} / \mathrm{kg}$ 宛 4 頭に筋注したところ， 1〜2 時間で $40 \sim 85 \mu \mathrm{g} / \mathrm{ml}$ の 血中濃度を示したが, 漸次低下して, 7 時間目には 4.3 $13.0 \mu \mathrm{g} / \mathrm{ml}$ である. しかも KM は春髄中にも速やかに 移行し，その濃度は血中濃度に影響されるとのことであ る. そして KM は筋注および皮下注によるときは速や

\footnotetext{
* 日本獣医畜産大学
}

かに吸収かつ排泄されるが，経口投与によるときは吸収 が悪いとのべている.

また二宮らが $20 \mathrm{~kg}$ の山羊に，KM 1,500 mg（力価） を筋注した後, 経時的に血中濃度を測定した実験では, 30 分で最高濃度を示し，これは 6 時間まで高濃度を維持 したが，24時間では認められなかったといら．そして実 験山羊は 24 時間で殺処分, 諸蔵器の KM 分布状態をみ たところ，尿がもっとも高く，ついで腎，血液，肺， 心, 肝および脾の順に低い值を示し, 脳, 脊髄および眼 房水恃全経過を通じ，KM を証明し得る濃度を示さなか ったと報告されている。

つぎに KM は各種病原菌に作用するが，とくに結核 菌16 18) およびそのほかの耐性菌にも有効とされ，人の 結核病1) はもちろん, 一般の急性感染症をはじめ外科的 感染症3にも卓効のあることが認められた.

さらに KM は，ほかの抗生物質と併用するとき，そ の効果が顕著で, 藤井はテトラサイクリンを併用する場 合がもっとも共力作用が大きく，ついでペニシリンおよ びクロラムフェニコールであるとのべた. またLAMBELIN は獣医領域で, ペニシリンとの共力作用の大きいことか ら, 両者の合剤をカナシリンとして, 多くの家畜の感染 症に用いるほか, KMの単独治療も行ない, 治癒率77.3 \%の成績をあげた。

すなわち KM は, 諸感染菌に広大な阻止作用をあら わす，わが国で発見された抗生物質であるが，わが獣医 臨床面では KM の家畜への応用はあまり検討されてい ない. 著者らは今回, 家畜に打ける諸感染症に $\mathrm{KM}$ を 応用し，若干の興味ある所見を得た。よってその結果の 概要を報告し，諸賢の批判を仰がんとするものである.

\section{供試動物和よび試験方法}

\section{1. 供試動物}

供試された動物は, 犬 28 頭, 猫 2 頭, 和牛 10 頭, ホル系乳牛 3 頭, 馬 1 頭执よび豚 5 頭, 計 49 頭である. このらち犬では 28 頭のうち 17 頭がジステンパーと診 断され, そのほかの動物では呼吸器感染症のほか各種の 感染をみたものである. その状況は第 1 表に示したとお りである。

\section{2. 供試薬と注射法}

供試した薬剤は硫酸カナマイシンの溶液である. 薬剤 は1日 1 回宛, 犬 $0.25 \sim 0.5 \mathrm{~g}$, 猫 $0.25 \mathrm{~g}$, 成牛 $5 \mathrm{~g}$, 犢 
1 3 g，馬 $5 \mathrm{~g}$ ，成豚 2〜3 $\mathrm{g}$ および子豚 $0.5 \mathrm{~g}$ を，それ ぞれ 1 回〜数回筋肉内に注射した。 なお Penicillin(以下 $\mathrm{PC}$ と略称) - Sulfa 剂(以下サ剂と略称)・ジステンパ 一免疫血清・副腎皮質ホルモンなどを治療の初期に用い たが，効果なくして $\mathrm{KM}$ を用い，あるいは $\mathrm{KM}$ と $\mathrm{PC}$ を併用した例も多い.PC は小動物では1 回 20〜30万 IU また大動物では 100〜300万 IU，ホルモン剂は小動 物で $1 \sim 2 \mathrm{mg} / \mathrm{kg}$ 用いた.

また病勢に応じてビタミン剂・ブドウ糖・強心剂・強 肝剂などを適宜使用した。

\section{3. 観察方法}

供試動物はすべて家畜病院または診療所で, 診療の対 象とされたものであり，ある例については血液拉よび尿 などの理化学的検査を試みた，そして転帰の判定には， もっぱら一般臨床所見の正常化をもって治癒とみなし た。

\section{試 験 成 績}

\section{1. 小動物に対する応用成績}

小動物は第 1 表に示したごとく，大部分が犬である. 犬の種類はセパード，コリー，ボクサー，ポインター， 土佐, スピッツ, ワイヤの洁か雑種である. 年令は最少 生後 4 月, 最高 5 才, 平均 2 才で, 体重は $3 \sim 20 \mathrm{~kg}$ 平 均 $11 \mathrm{~kg}$ であった.

(1) 犬のジステンパー
犬ジステンパーと診断されたのは，生後 4 月ないし 2 年平均 1 年 1 月のものであった。病勢は重症が 12 頭, 中症が 2 頭および軽症が 3 頭である．病性は第 1 表に示 すと和り, 臨床観察結果から, 眼型・呼吸器型・神経型・ 胃腸型の 4 型に区分して整理した。 もっとも多いのは気 管支炎ないし気管支肺炎の呼吸器型が 8 頭，ついでチッ クおよびテンカン症状を現わした神経型が 5 頭，そのほ か眼型 3 頭および胃腸型 1 頭である.

眼型の 3 頭は，KM を 1 回 $0.5 \mathrm{~g}$ 宛 $1 \sim 4$ 回をたこれ にPCを併用した.このうち 2 頭はそれぞれサ剤および ホルモン剤を用いた．その結果 3 頭とも $3 \sim 7$ 日，平均 5 日で回復した.

呼吸器型では, 気管支炎 6 頭および気管支肺炎 2 頭, 計 8 頭であるが，後者のうち 1 頭は死亡した. $\mathrm{KM}$ は 1 回 $0.25 \sim 0.5 \mathrm{~g}$ 平均 $0.41 \mathrm{~g}$ 宛 $2 \sim 6$ 回平均 4.1 回注射し て，6〜12 日平均 8.3 日で 7 頭が治癒した. このうち 4 頭ははじめに PC のほか血清・サ剤・ホルモン鼡などを 用いたが効果なく，ついで $\mathrm{KM}$ を使用した。 また 1 頭 は PC と血清で解熱せず， $\mathrm{KM}$ と PC の併用によって 回復し，2頭は PC とホルモン剂および PC と血清で好 転せず，ともにＫM を用いたものである.

神経型では 5 頭のうち 2 頭は硬蹠症と診断されたもの である.この群には $\mathrm{KM}$ を 1 回 $0.25 \sim 0.5 \mathrm{~g}$ 平均 0.47 $\mathrm{g}$ 宛 $1 \sim 5$ 回平均 3.4 回注射し, そのほか PC - 血清・

第 1 表 小動物に対する Kanamycin の応用成績

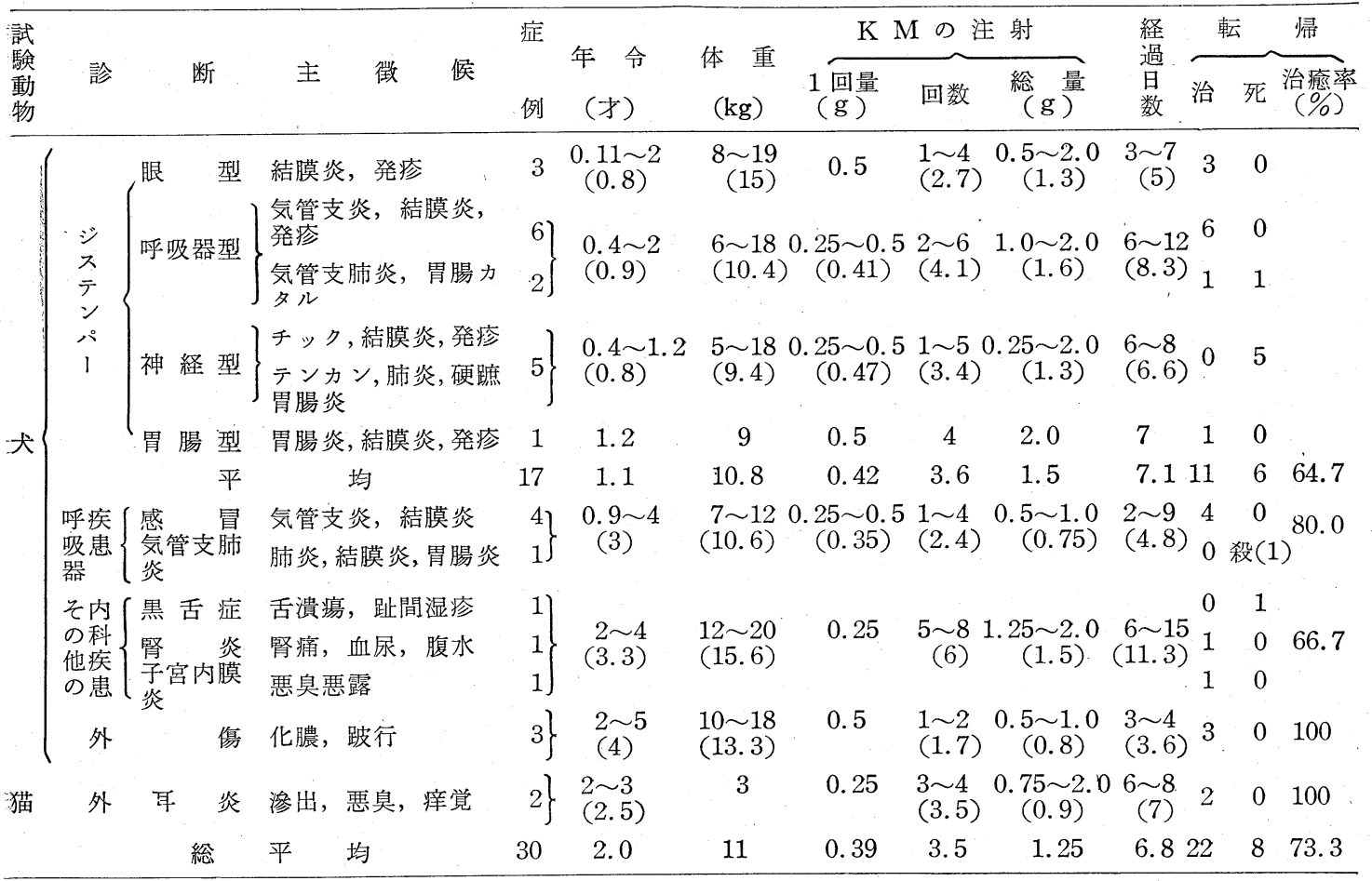


第 2 表 KMによる腎炎の治療（雑種，4才，）

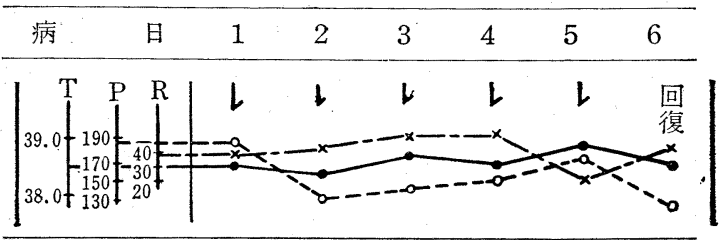

\begin{tabular}{|c|c|c|c|c|c|c|c|}
\hline & 元気消失 & + & + & + & - & - & - \\
\hline 臨 & 食欲廃絶 & + & + & + & - & - & - \\
\hline $\begin{array}{l}\text { 床 } \\
\text { 所 }\end{array}$ & 貧 & H & W & 井 & 卅 & H & + \\
\hline 見 & $\begin{array}{ll}\text { 腹 } & \text { 水 } \\
\text { 䀒臓肥大 }\end{array}$ & $\begin{array}{l}H \\
+\end{array}$ & H & $H$ & H & + & + \\
\hline
\end{tabular}

\begin{tabular}{|c|c|c|c|c|c|c|c|}
\hline & （尿 & 赤褐 & 赤褐 & 黄褐 & 淡黄褐 & 濃褐 & 淡黄 \\
\hline 永 & 糖 & - & - & - & - & - & - \\
\hline 見 & 蛋 白(\%) & 0.15 & 0.3 & 0.3 & 0.2 & 0.2 & 0.2 \\
\hline シ & アセトン & \pm & \pm & - & - & - & 一 \\
\hline 广 & ビリルビン & H & H & $H$ & $H$ & + & - \\
\hline र & $\begin{array}{l}\text { ウロビリノ } \\
\text { ーゲン }\end{array}$ & - & - & - & + & - & - \\
\hline$\smile$ & （潜 & + & + & + & + & - & - \\
\hline 尿 & 球 & + & & & & & - \\
\hline 渣 & 球 & + & & & & & - \\
\hline $\begin{array}{l}\text { ギ } \\
\text { 厶 }\end{array}$ & 赤血球残壊 & + & & & & & - \\
\hline ザ & (上皮細胞 & + & & & & & - \\
\hline & Erythro. (万) & 246 & & & & & 222 \\
\hline 血 & Leuco.(百) & 386 & & & & & 280 \\
\hline 液 & $\mathrm{Hb} \quad(\%)$ & 48 & & & & & 31 \\
\hline & $\mathrm{pH}$ & 7.85 & & & & & 7.4 \\
\hline 白 & Eos. & 1.0 & & & & & 0.5 \\
\hline 球 & Rod. & 44.0 & & & & & 31.5 \\
\hline 百 & Seg. & 35.5 & & & & & 58.5 \\
\hline 比 & Ly. & 15.0 & & & & & 7.0 \\
\hline$\%$ & Mon. & 4.5 & & & & & 2.5 \\
\hline
\end{tabular}

\begin{tabular}{|c|c|c|c|c|c|c|c|c|c|}
\hline \multicolumn{5}{|c|}{ カナマイシン○ } & 0 & 0 & 0 & 0 & \\
\hline 治 & 栄 & 養 & 剂 & 0 & 0 & 0 & 0 & 0 & \\
\hline \multirow{2}{*}{ 療 } & 強 & 心 & 剤 & & 0 & 0 & 0 & 0 & 0 \\
\hline & 強 & 肝 & 剤 & 0 & 0 & & 0 & 0 & 0 \\
\hline
\end{tabular}

ホルモン剤などを用いたが， 6 〜 8 日平均 6.6 日で全例 が死の転帰をとった。

胃腸型は 1 頭で, KM 1 回 $0.5 \mathrm{~g} 4$ 回注射のほかホル モン剤を1回併用し，7日で回復した.

すなわちジステンパーでは，神経型以外のものはほと んど回復し，その治癒率は 17 頭のうち 11 頭で $64.7 \%$ である。

(2) 呼吸器疾患

一般呼吸器疾患として扱ったもののらち，4頭は平均 3 才で, 気管支炎および結膜炎の徴を示し感冒と診断さ
れ，また 1 頭は生後 9 月で気管支肺焱をおこしていた。

$\mathrm{KM}$ は 1 回 $0.25 \sim 0.5 \mathrm{~g}$ 平均 $0.35 \mathrm{~g}$. 宛 $1 \sim 4$ 回平均 2.4 回注射されたが，気管支肺炎例は予後不良のため畜 主の要望により殺に付し, ほかの 4 頭は平均 4.8 日で治 癒した。

(3) 一般内科的疾患

黒舌症と診断された 1 頭は，2次感染による舌の潰瘍 と趾間の湿疹を認めた．また腎炎の1頭は腎痛と血尿の ほか腹水を併発し，さらに1頭の子宮内膜炎では不潔膿 様の悪臭ある悪露排出がみられた.

この 3 例ははじめから $\mathrm{KM}$ を用い, 1 回 $0.25 \mathrm{~g}$ 宛 5 $\sim 8$ 回平均 6 回注射した. その結果，黒舌症は 13 日目 に死亡したほか，ほかの 2 頭は 6 日拉よび 15 日で治療 した.すなわち $\mathrm{KM}$ の注射後は, 次第に解熱・尿の正 常化・腎痛の消退および悪露の正常化をみたものであ る.

（4）外，傷

下肢执よび背部の外傷の化膿により跛行を呈した 3 頭 に, $\mathrm{KM}$ を 1 回 $0.5 \mathrm{~g}$ 宛 $1 \sim 2$ 回注射したところ, 3 〜 4 日平均 3.6 日で諸徵の消退をきたした.

(5) 猫の外耳炎

猫では 2 頭の外耳炎の治療を試みた。すなわち悪臭を 伴なった滲出物のほか痒覚が著明で, かつ周团の脱毛を みたが，KM を1回 $0.25 \mathrm{~g}$ 宛 $3 \sim 4$ 回平均 3.5 回注射 した結果，1頭は6日ほかの 1 日頭は8 日でそれぞれ治癒 した.

\section{2. 牛に対する応用成績}

$\mathrm{KM}$ の牛に対する応用成績は, 第 3 表にその概要を示 した. すなわわ成牛では, 平均 5.6 ( $3 \sim 9$ ) 才の褐毛 和種 5 頭および平均 $3.6(3 \sim 5)$ 才のホル系乳牛 3 頭 計 8 頭である. 成牛では呼吸器系疾患と肝膿瘍である. また犢は褐毛和種 5 頭で, 平均 $3.8(2 \sim 8)$ 月のもの であり，下痢をたは気管支炎之䛦断された例である.

\section{（1）成牛の治療成績}

褐毛和種では気管支肺炎が 4 頭であったが，いずれも 発熱・濃稠鼻汁の排出・哑嗽の泳か, 呼吸促進およびラ ッセルなどが主徴であった. $\mathrm{KM}$ は 1 回平均 4.6 (3〜 $5) \mathrm{g}$ 宛 $2.4(1 \sim 4)$ 回注射し, またPCを300万 IU 宛 $2 \sim 3$ 回用いた. その結果 $5 \sim 8$ 日平均 5.2 日で治癒 した。 また和牛の肝膿瘍は, 抢そらく異物の燕下による 創傷性胃炎の継発症と思われるが，高熱持続の重症例 で, $\mathrm{KM}$ を 1 回 $5 \mathrm{~g}$ 宛 3 回また $\mathrm{PC}$ を 300 万IU 宛 2 回 注射したが，7 日の経過で死の転帰をとった。

ホル系乳牛では 3 頭が気管支炎と診断され，鼻汁の排 出打よび咳嗽を主徴とし, $\mathrm{KM}$ を 1 回 $5 \mathrm{~g}$ 宛 $1 \sim 2$ 回と PC を注射した結果， $2 \sim 3$ 日平均 2.3 日の経過で治療 した. 
第 3 表 大・中動物に対する Kanamycinの応用試験

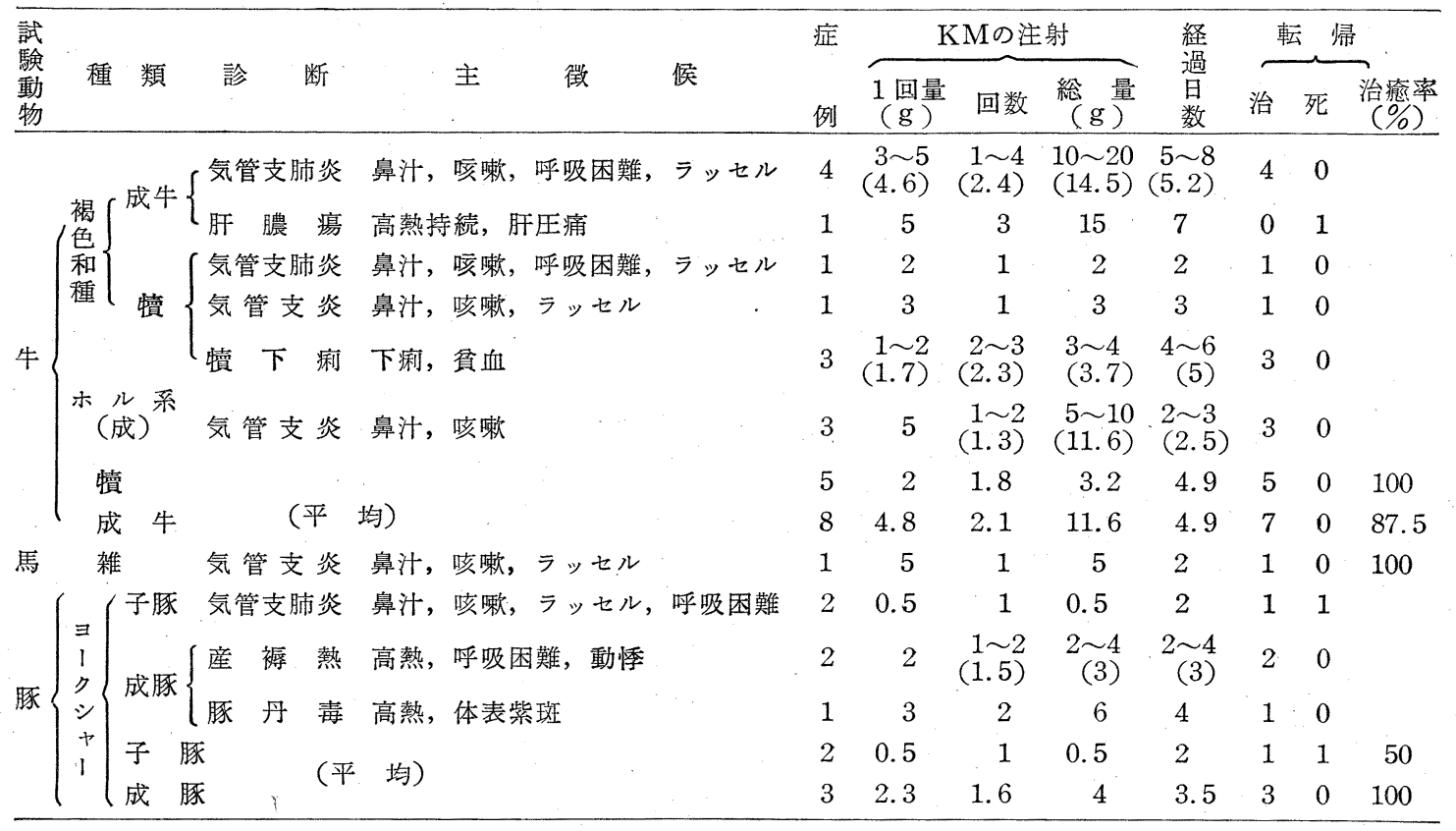

（2）犢の治療成績

犢下痢と診断された 3 頭は, 貧血敊よび水瀉下痢が主 徵で, $\mathrm{KM}$ を1回 1 2 g 宛 $2 \sim 3$ 回注射した。 そのほ かサ剂拉よび PC を用いたが, 経過 4 〜 日平均 5 日で 全例が治癒した.

\section{3. 馬に対する応用成績}

馬は 5 才の気管支炎 1 頭である. その主徴は濃稠鼻汁 の排出, 頻回の発咳および肺の湿性ラッセルなどであっ た. $\mathrm{KM}$ を 1 回 $5 \mathrm{~g}$ 注射し, 2 日で回復した.

\section{4. 豚に対する応用成績}

豚では子豚の気管支肺炎 2 頭, 成豚の産裖熱 2 頭就よ 第 4 表 牛の気管支肺炎の経過（和種, 3 才, 우)

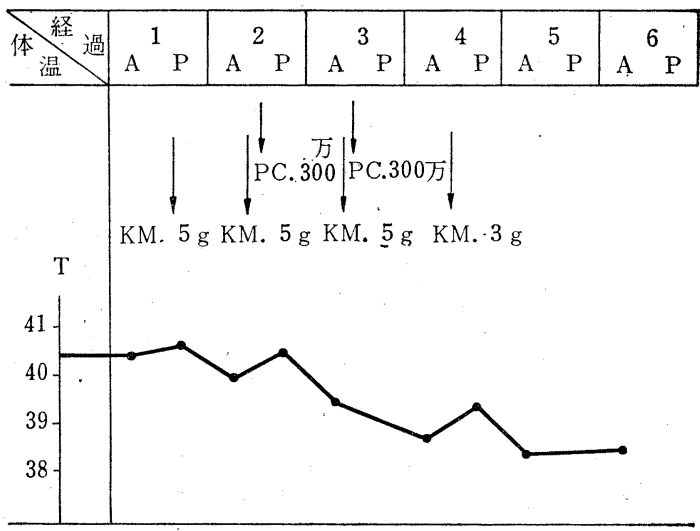

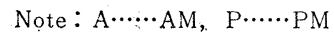

び豚丹毒 1 頭, 計 5 頭が供試された.

気管支肺炎はともに生後 2 月の豚にみられ，鼻汁の排 出，発咳执よび肺のラッセルが主徴であった。これには $\mathrm{KM}$ を 1 回 $0.5 \mathrm{~g}$ それぞれ注射したところともに 2 日で 回復した.

また年令 2 拈よび 3 才の 2 頭の産裖熱例は，KM を 1 回 $2 \mathrm{~g}$ 宛それぞれ 1 および 2 回注射し，同時に $\mathrm{PC}$ 用いたところ， 2 および 4 日で回復をみた。

さらに 1 頭は 2 才で豚丹毒に罹病したものであるが， KMを 1 回 $3 \mathrm{~g}$ 宛 2 回注射するとともに PC を100万IU 宛 2 回併用した結果, 4 日で回復した.

以上牛・馬・豚・犬・猫の感染症に, KM 治療的に 用いた成績の概要をのべたのであるが，副作用と思われ るものなく，その効果はすぐれている。とく $\mathrm{PC}$ また はほかの薬剤で効なきものに KM を使用し，あるいは $\mathrm{KM}$ と PC を併用するときは，さらにいちじるしく治 療効果を発揮するようである.

\section{考察}

著者らは犬に执いて, ジステンパー 17 頭, 一般呼吸 器疾患 5 頭, その他内科的疾患 3 頭执よび外科的疾患 3 頭に，それぞれ KM を主体として治療試験を行ない， それぞれ $64.7 \% ， 80 \% ， 66.7 \%$ 拈よび 100\% の治瘾率 をみた。京た猫では 2 頭の外耳炎を $\mathrm{KM}$ で治療したと ころ, 両者とも治瘾した. 神経型のジステンパーは全例 が死亡し，その結果小動物では，30 頭のうち 22 頭すな わち $73.3 \%$ 治瘾したものである.

日獣会誌 18 (1965) 
小動物に対する KM の注射量は, UMEZAWA ら11,12) および TISCH らの実験結果を参考に， 1 回量を 0.25 $0.5 \mathrm{~g}$ とし, 平均 3.5 回筋注したのであるが，なんら注 射反応は認められなかった．とくにジステンパー拈よび その棌かの重性内科的感染症では, その多くが 2 次感染 菌によるものと思われ，はじめ P Cなどが用いられたが 病勢の好転を久ず，よって $\mathrm{KM}$ を応用された例が多

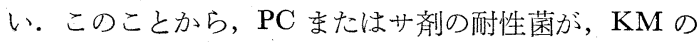
応用によって発育を阻止され，治痖の転帰をとったもの のようである。 また KM と PCの併用によって，いち じるしく病勢を好転せしめることから，これは両者の相 乗作用によるものと考㝋られる.

また牛では, 褐色和種およびホル系の呼吸器敊よび消 化器系の感染症 13 頭であった。瓄では KM を 1 回 2 $(1 \sim 3) \mathrm{g}$ 宛平均 1:8(1〜3) 回注射し, 全例が治瘾 した. また成牛では 1 回 $4.8(3 \sim 5) \mathrm{g}$ 宛 2.1 (1〜 4) 回の注射で $87.5 \%$ の治痖をみた。馬は気管支炎の 1 頭であったが， $5 \mathrm{~g}$ を1回注射して 2 日で治痖した. すなわら牛および馬の注射量は, 著者ら6)の実駼結果か ら想定したのであるが，きわめて好成績を収めた。

つぎに 5 頭の患豚のうち 2 頭の子豚は生後 2 月の肺炎 例で, $\mathrm{KM}$ は $0.5 \mathrm{~g}$ 宛 1 回, 女た成豚の産裖熱 2 頭拉よ び豚丹毒 1 頭は $2 \sim 3 \mathrm{~g}$ 宛 $1 \sim 2$ 回それぞれ注射したが, 子豚1頭のみが死亡したほかはすべて回復している。そ して牛拉よび豚の例でも， $\mathrm{KM}$ と PC を併用したもの が多いが, 小動物の場合と同様, 病勢の好転がきわめて 速やかである.すなわち大・中動物の治癒率は，19頭の らち 17 頭で $89.5 \%$ であった.

LAMBELIN は KM を1回少なきは $375 \mathrm{mg}$ 多きは -3,000 mg 単独で，をたこれに PC を少なきは $100 \mathrm{IU}$ 多きは $300 \mathrm{IU}$ 混じて乳牛の諸感染症の治療を試みた が, 注射量和よび回数は一定していない.すなわち子牛 の大腸菌感染 7 頭, 乳房炎 5 頭, 気管支肺炎 8 頭, 壊瘨 性桿菌症 (趾間腐爛) 17 頭, 喉頭炎 1 頭, 放線菌症 4 頭, 慢性子宮内膜炎 26 頭拉よび豚丹毒 2 頭, 計 230 頭を治療 したところ，178 頭(77.3\%) は完全治癒，13頭(5.6\%) は症状好転および 39 頭 (17\%) は無効であったと報じ ている. 氏らの応用法をみると, 拈拈む称 24 時間に 2 $\sim 3$ 回注射後に解熱し, 症状の好転をみ, とくに子牛の 急性型の症例では KM を 1 回 $3 \mathrm{~g}$ 注射して解熱したも のもある.

著者らの今回の試験では, 梅沢ら，Trsch ら，TAKEUCHI ら，MAEDA らおよび二宮らの基礎試験成績と，ま た著者らの牛・馬についての血中濃度測定結果とを参考 に, それぞれ 1 回の注射量を定めた. そして各症例の治 療に応用したところ、拈和む散待すべき成果をおさめ たものと考光る。

\section{総括}

著者らは, 褐毛和種 10 頭, ホルスタイン系乳牛 3 頭, 馬 1 頭, 豚 5 頭, 犬 28 頭および猫 2 頭, 計 49 頭の 家畜の諸感染症に，硫酸カナマイシンを治療的に用い た、またペニシリン，サルファ剤および栄養剤なども併 用した，成績の概要をのべるとつぎのとおりである.

1） 8 例の成牛のうち，4 例は気管支肺炎， 3 例は気 管支炎および 1 例は肝膿瘍と診断された。 カナマイシン は 1 日 $3 \sim 5 \mathrm{~g}$ (平均 $4.8 \mathrm{~g}$ ) 宛 $1 \sim 4$ 日 (平均 2.1 回), 総量 $11.6(5 \sim 20) \mathrm{g}$ 注射したところ, 経過 4.9（2〜 $8 ）$ 日で， 8 例のうち 7 例 $(87.5 \%)$ は治癒し， 1 例は 死亡した.

2） 5 例の憒では，2 例が気管支炎と気管支肺炎で， ほかの 3 例は犢下痢であった. カナマイシンは 1 日 1 〜 $3 \mathrm{~g}$ (平均 $2 \mathrm{~g}$ ) 宛 $1 \sim 3$ 日 (平均 4.9 日) 注射したとこ ろ，2〜6日（平均 4.9 日）で全例が治瘾した.

3）馬は気管支炎の 1 頭であったが，カナマイシンを $5 \mathrm{~g} 1$ 回注射し, 2 日で回復した.

4） 3 例の成豚では， 2 例が産裖熱㧍よび 1 例が豚丹 毒に罹病していた. カナマイシンは1日 1 回 2 3 g (平 均 $2.3 \mathrm{~g})$ 宛 $1 \sim 2$ 日注射したところ, $3.5(2 \sim 4)$ 日 で全例が治癒した。

5） 2 例の子豚は気管支肺炎であったが，カナマイシ ンを 1 回 $0.5 \mathrm{~g}$ 注射し, 経過 2 日で 1 例は治瘾したが 1 例は死亡した.

6） 25 例の犬では, 17 例がジステンパー， 1 例が気 管支炎，4例が気管支肺炎で，そのほか黒舌症・腎炎・ 子宮内膜炎・外傷に上る化膿がそれぞれ1例であった。 またジステンパーは, 3 例の眼型, 8 例の呼吸器型, 5 例の神経型㧍よび 1 例の消化器型に区分できた。ささらに 2 頭の猫は, ともに外耳炎であった。

これらの小動物には, カナマイシンを1日 $0.39(0.25$ $\sim 0.5) \mathrm{g}$ 宛 $1 \sim 6$ (平均 3.5) 日注射した. カナマイ シンの使用総量は $1.25(0.3 \sim 2.0) \mathrm{g}$ で, 30例のらち 22 例 $(78.3 \%)$ は 6.8 (3〜15) 日で治痖した. しかし神経 型ジステンパーの 5 例, 気管支肺炎の 1 例沶よび黒舌症 の 1 例は，それぞれ 6 13 日で死の転帰をとった。

7）以上の治療試験結果から，カナマイシンによる治 癒率は, 小動物では $73.3 \%$, 大動物では $92.8 \%$ および 豚では $80.0 \%$ であった。

8）カナマイシンとペニシリンとを併用すると，その 効果は顕著である.

9）発病の初期に、ペニシリンまたはサルファ剤など を用いたが効果なく，ついでカナマイシンの応用によっ て治癔した例が多い。

この成績の概要は，第 58 回日本獣医学会で講演発表 した。

日獣会誌 18 (1965) 


\section{文献}

1) 堂野前維摩郷：カナマイシンによる肺結核治療の 臨床的研究. Kanamycin Meiji， P. 55 64, 明治製菓 K K (1958). 2) 藤井俊次 : 小児科領域に括ける Kanamycin の検討. 同上, p. $73 \sim 75$ (1958). 3) 石山俊次 : 外科的感染症に対するカナマイシン療法. 同上, p. 77 〜89 (1958) 4) Lambelin, G., M. Dive, P. JoarletTe, L. Marchand : Essais Cliniques, on Pratique Rurale, de la Kanamycine Scule ou Associae á la Penicilline. Ann. Méd. Vét., 106, 252 267, (1962). 5) MAEDA, K., M. Ueda, K. Yagishita, S. Kawati, S. Konda, M. Murase, T. Takeuchi, Y. OKami \& H. Umezawa : Studies on Kanamycin, J. Antibiotics, Japan, Ser., A. 10, $228 \sim 231$ (1957). 6) 明治製菓 K K : カナマイシンの 血中濃度試験報告. (1958). 7) 長岐佐武郎：2，3の 急性感染症に対するカナマイシンの臨床応用. Kanamycin Meiji, p.65〜71. 明治製菓KK (19.58). 8) NAKAmura, R., M. Sonoda, K. Too \& T. KIKUCHI: Therapeutic treatment in canine distemper with chloromycetin and aureomycin. Jap. J.Vet. Res., 2, 67〜 72, (1954). 9) 二宮幾代治・佐藤修司・田中義一郎・川島秀雄 : 抗生物 質の体内分布に関する研究II. 硫酸七ドロストレプトマ イシン，硫酸カナマイシンおよび塩酸テトラサイクリン の山羊体内に和ける分布と消長について, 日獣学誌, 21, 学会号, 115 116 (1959) ; J. Antibiotics, Ser. B., 13, 1 ５ (1960). 10) Takeuchi, T., T. Hikiji, N. Nitta,
S. Yamazaki, S. Abe, H. Takayama \& H. Umezawa: Biological Studies on Kanamycin, J. Antibiotics, Jaban, Ser. A, 10, 107 114 (1957).

11) Tisch et al: Pharmacological Studies with Kanamycin. Ann. N. Y. Acad. Sci., 76, Art. 2, 54 65 (1957).

12) Umezawa, H., M. Ueda, K. Maeda, K. YagIshita, S. Kondo, Y. Okami, R. Utahara, Y. Osato, K. Nitta \& T. TAkibuchi : Production and Isolation of a new Antibiotic Kanamycin. J. Antibiotics, Japan, Ser., A., $10,181 \sim 188$ (1957). 13) 梅沢浜夫：カナマイシンの 発見と基礎的研究, Kanamycin Meiji, p. 1 16 (1958). 14) Umezawa, S., Y. Ito \& S. Fukatsu: The Biological Structure of Kanamycin. J. Antibiotics, Japan, Ser. A, 11, 120 121 (1958). 15) Umezawa, S., Y. Iтo, S. Fukatsu \& H. Umezawa: Lawer Toxic derivatives of Antibiotics. J. Antibiotics, Japan, Ser. A, 12, 114 115 (1959). 16) Yanagisawa, K. \& N. Sato: Studies on Kanamycin, a new Antibiotic Against Tubercle Bacilli, I.J. Antibiotics, Japan, Ser. A, 10, 233 235 (1957). 17) Yanagisawa, K., K. Kanai \& T. TAchibana: Studies on Kanamycin, a new Antibiotic Against Tubercle Bacilli. II. J. Antibiotics, Japan, Ser. A, 10, 236 241 (1957). 18) 柳沢 謙: Kanamycin の抗酸菌に関する試験管内実験 と動物実験について, 医学生物学最近の展望, 第 I 集, p. $217 \sim 247$. 国立予防衛生研究所 (1960).

Therapeutic treatment with kanamycin in domestic animals

Michiya Arisawa, Takeshi Takahashi, Tomiya Uchino, Tsutomu Watanabe, Takao Nakai Sohei Noda and Ryoichi Nakamura (Nippon Veterinary and Zootechnical College, Musashino P. O., Tokyo)

\section{SUMMARY}

A total of 49 cases of various diseases were treated by intramuscular injection with kanamycin sulfate solution.

1) Eight adult cows affected with bronchopneumonia, bronchitis, or liver abscess were injected with 3 to $5 \mathrm{~g}$ daily for 1 to 4 days. Seven of them recovered in 2 to 8 days.

2) Five calves affected with bronchitis, bronchopneumonia, or calf scour were injected with 1 to $3 \mathrm{~g}$ daily for 1 to 3 days. All of them recovered in 2 to 6 days.

3) A horse affected with bronchitis was given once and recovered in 2 days.

4) Three adult swine affected with puerperal fever or erysipelas were injected with 2 to $3 \mathrm{~g}$ once or for 2

\section{東京(府中)競馬場飞伝貧発生}

東京競馬場では 9 月30日から10月11日までのあいだに 馬伝染性貧血16頭が発生し, らち10頭を殺処分した.

8 月22日不明熱発をみる馬が発生し，9月8～22 日の あいだに多数の馬が発熱した. 東京競馬場診療所では, days and recovered in 2 to 4 days.

5) Two piglets suffering from bronchopneumonia were injected with $0.5 \mathrm{~g}$ once. One of them recovered in 2 days, and the other died at 2 days.

6) Twenty-eight dogs affected with distemper, bronchitis, bronchopneumonia, black tongue, nephritis, endometritis, and suppurative trauma and 2 cats with external otitis were injected with $0.25 \times 0.5 \mathrm{~g}$ daily for 1 to 6 days. Of the 30 cases, 22 recovered in 3 to 15 days.

7) The rate of recovery due to kanamycin therapy was $73.3 \%$ in the small animals, $92.8 \%$ in the large animals, and $80.0 \%$ in the swine.

8) When injected jointly with penicillin, kanamycin seemed to show a powerful antibacterial effect.

日獣会誌 18 (1965)

9 月 30 日, $41.9^{\circ} \mathrm{C}$ の発熱馬を検査し, 熱型から伝貧を疑い 血液検査を行なったところ,多数の担鉄細胞を検出し, 10 月 1 日真症と決定した. 10月 7 日までに全馬について伝 貧検診を行ない, 計 16 頭の患畜を摘発し, 10月 6 日, 2 頭, 10月 8 日，8頭をすでに殺処分した。（635頁へつづく） 